\title{
Artes liberais e ofícios mecânicos nos colégios jesuíticos do Brasil colonial
}

\author{
AMARILIO FERREIRA JR. \\ Universidade Federal de São Carlos \\ MARISA BITTAR \\ Universidade Federal de São Carlos
}

\section{INTRODUÇÃO}

Este artigo tem como objetivo tratar da relação entre artes liberais e ofícios mecânicos no âmbito dos colégios jesuíticos do Brasil colonial (1549-1759).

Constituídos para desempenhar papel estratégico na formação dos quadros intelectuais, religiosos e civis, que iriam propagar o cristianismo nas terras brasílicas, os colégios eram verdadeiros lócus irradiadores da tradição humanística greco-romana cristianizada pela Igreja católica ao longo da Idade Média. Esse processo teve início no século IV, com a patrística neoplatônica, e finalizou-se nos séculos XI-XII, com o tomismo aristotélico. Para tanto, a Companhia de Jesus prescreveu no Ratio studiorum, durante quase cinquenta anos de elaboração (1551-1599), os conteúdos das humanidades latinas, das classes inferiores às superiores, considerados fundamentais para a formação dos "soldados de Cristo". Esses deveriam empenhar-se na restauração da antiga hegemonia ideorreligiosa exercida pela Igreja católica até 1517, data que marcaria o início da cisão cristã na Europa ocidental.

Uma vez elaborado o plano de estudos da Companhia de Jesus, ou seja, o Ratio studiorum, todos os seus colégios ficaram obrigados a adotá-lo. A necessidade de uniformizar procedimentos, centralizar decisões e obedecer a uma única diretriz filosófica foi o que motivou o surgimento desse importante plano, uma vez que os colégios se multiplicavam em muitos lugares, particularmente na Europa, fazendo com que a direção da Companhia de Jesus temesse pela dispersão de ações. 
Pesquisas que realizamos anteriormente mostraram o caráter de improvisação que marcou a ação pedagógica jesuítica no Brasil até o final do século XVI, quando as condições concretas aqui encontradas foram mais fortes que os preceitos educacionais professados pela Companhia. Ao conjunto de improvisações praticadas nesse período anterior ao Ratio, denominamos pedagogia brasílica. Dando continuidade a esses estudos, apresentamos agora outra face da atuação pedagógica jesuítica, isto é, o ensino de ofícios manuais. Conforme será mostrado no decorrer deste artigo, essa face também foi marcada pelo traço de necessidade que se impôs perante o meio, acima de prescrições doutrinárias. Além disso, as artes mecânicas não foram consideradas na elaboração do Ratio studiorum, que entrou em vigor em 1599, embora uma sistematização de suas regras já estivesse consagrada na Monumenta pedagogica, de 1570. Aqui procuramos mostrar que nas terras do Novo Mundo a missão jesuítica extrapolou a constituição de colégios regidos pelo Ratio studiorum, porque, desde o início, o seu complexo - composto de fazendas, colégios, residências e igrejas necessários à evangelização - foi obrigado a contar também com oficinas de artes mecânicas anexas para fabricar as manufaturas essenciais que garantissem a sua existência.

As fontes consultadas neste estudo mostram que o segmento de oficiais mecânicos não era composto apenas pelos colonos livres vindos da metrópole, indígenas ou escravos desafricanizados, mas também pelos próprios padres jesuítas, como José de Anchieta e Antonio Vieira; o primeiro no século XVI, e o segundo no século XVII. Ambos se constituíram em casos emblemáticos de intelectuais da ordem colonial que trabalharam com o cérebro e com as mãos. Anchieta não foi somente um "cientista das letras" que gramaticou o tupi, a língua mais falada na costa leste brasílica; foi também um fabricador manual de alpercatas, o principal calçado utilizado pelos jesuítas no Brasil colonial. Vieira, por sua vez, um dos grandes luminares da língua portuguesa de todos os tempos, exerceu o ofício de construtor de igrejas. No "Sermão da epiphania", pregado na capela real para a Corte metropolitana, depois da expulsão dos jesuítas do estado do Maranhão (1661), o famoso pregador assim se referiu às lidas atinentes ao mestre de obras:

Edificamos com eles [os ameríndios] as suas igrejas, cujas paredes são de barro, as columnas de pau tosco, e as abobadas de folhas de palma, sendo nós os mestres e os obreiros d'aquela architectura, com o cordel, com o prumo, com a enxada, e com a serra, e os outros instrumentos (que também nos lhes damos) na mão. (Vieira, 1945, p. 43)

Com base em pesquisa documental, a hipótese aqui adotada é a de que o complexo jesuítico difundia a cultura latina cristã, sua principal função, mas ao mesmo tempo ensinava ofícios e produzia mercadorias, imbricando trabalho intelectual com trabalho manual. A existência dessa relação permite considerar os colégios como unidades que estavam estruturadas nas regras do Ratio studiorum e também nas oficinas anexas de instrução de artes mecânicas. Procuramos fazer, portanto, uma abordagem histórica da relação entre educação e trabalho na ação pedagógica dos jesuítas no Brasil colonial. 


\section{AS ARTES LIBERAIS NOS COLÉGIOS JESUÍTICOS COLONIAIS}

O projeto educacional implantado pela Companhia de Jesus no Brasil durante o século XVI era parte integrante da estratégia colonizadora propugnada pela Coroa portuguesa. Engajado nas guerras religiosas travadas entre católicos e protestantes que assolaram a Europa, o padroado ${ }^{1}$ lusitano ajudou a expandir o capitalismo mercantil por meio das grandes navegações e a propagar a fé católica entre os denominados "povos bárbaros" que habitavam as terras além-mar. Assim, a criação de colégios no mundo colonial português estava associada tanto aos interesses mercantis quanto ao processo de propagação dos valores professados pela civilização ocidental cristã. Tal imbricação mercantil-religiosa pode ser auferida pelo papel que desempenharam os últimos reis da Dinastia de Avis (1385-1580) durante a expansão dos seus domínios ultramarinos. Em 1554, por exemplo, D. João III (1521-1557) escreveu ao governador-geral do Brasil, D. Duarte da Costa (1553-1557), recomendando a edificação de um colégio em Salvador "conforme ao desta cidade [Lisboa]" (D. João III, 1957, p. 36-37).

Depois, em 1564, o rei D. Sebastião I (1557-1578), sucessor de D. João III no trono português, assinou o alvará régio que estabelecia a redízima, fração dos dízimos cobrados no âmbito da colônia, como fonte de financiamento do colégio jesuítico da Bahia, construído pelo seu antecessor. O referido documento estabelecia que:

[...] eu e os reis destes reinos meus subcessores, governadores e perpetuos administradores [...] vendo quam apropriado o Instituto dos Padres da Companhia de Jesus he para a conversão dos infieis e gentios daquellas partes e instrução dos novamente convertidos, ter mandado alguns dos ditos Padres as ditas partes do Brasil cõ intenção e determinação de nellas mandar fazer e fundar collegios a custa da sua fazenda [...]. E depois de avida a dita informação, assentey cõ parecer dos do meu cõselho, de mandar acabar nas ditas partes hum collegio da dita Companhia na cidade do Salvador da capitania da Baya de todos os Santos, onde já está começado; o qual collegio fosse tal que nelle podessem residir e estar até sessenta pessoas da dita Companhia, que parece que por agora deve aver nelle pellos diversos lugares e muitas partes em que os ditos Padres residem e a que do dito collegio são enviados pera bem da conversão e outras obras de serviço de Nosso Senhor, e pera sostentação do dito collegio e religiosos delle ey por bê de lhes aplicar e dotar, e de feito por esta minha carta de doação doto e aplico huma redizima de todos os dizimos e direitos que tenho e me pertencem e ao diante pertencerem nas ditas partes do Brasil. (D. Sebastião I, 1938, p. 538-539)

1 O reino de Portugal foi constituído, em 1140, sob o protetorado da Santa Sé, que exercia o poder político e religioso supranacional na Europa ocidental, contra os interesses dos reis de Leão e Castela, durante a guerra de expulsão dos mulçumanos da Península Ibérica. Por isso, a Coroa portuguesa sustentou, desde a sua origem, a fé católica apostólica romana como religião oficial do Estado monárquico. 
Por sua vez, o padre Manuel da Nóbrega, primeiro provincial da Companhia de Jesus no Brasil, de 1555 a 1559, em carta de 1561 ao padre Diego Laynes, ${ }^{2}$ defendia a criação de colégios, pois os considerava indispensáveis para "remediar a perdição de almas” e converter as crianças indígenas ao cristianismo:

Nesta terra, Padre, temos por diante muito número de gentios, e grande falta de operários. Devem-se abraçar todos os modos possíveis de os buscar, e perpetuar a Companhia nestas partes, para remediar tanta perdição de almas. E se aqui é perigoso criá-los [meninos], porque têm mais ocasiões para não guardar a castidade depois que se fazem grandes, mandem-se antes deste tempo para à Europa, assim dos mestiços, como dos filhos dos gentios, e de lá nos enviem quantos estudantes moços puderem para cá estudar em nossos Colégios, porque nestes não há tanto perigo, e estes juntamente vão aprendendo a língua da terra, que é a mais principal ciência para cá mais necessária, e a experiência tem mostrado ser este útil meio. Porque alguns dos órfãos, que de Portugal enviaram, que depois cá admitimos na Companhia [padres Simeão Gonçalves, Manuel Viegas, João Pereira e António de Pina], são agora muito úteis operários. Esta troca queria eu fazer ao princípio, e enviei alguns mestiços, e deles um está agora em Coimbra [padre Cipriano do Brasil], mas fui avisado que não mandasse mais. Se não se há-de fazer conta senão dos operários, que se enviam de Espanha, segundo vêm poucos, e se acabam os que cá estão, muito devagar irá a conversão desta gentilidade. (Nóbrega, 1955, p. 390-391)

Para acelerar "a conversão desta gentilidade", a instituição escolar jesuítica no Brasil não nasceu propriamente das normas prescritas, até porque os dois mais importantes documentos institucionais que passariam a regular o funcionamento da ordem jesuítica ainda estavam em processo de elaboração: as Constituições... $(1558)^{3}$ e o Ratio studiorum (1599). No início, a instituição escolar tratava-se apenas de uma rústica escola de ensino das primeiras letras. As casas de bê-á-bá, termo com o qual designamos o ensino das primeiras letras nas casas coabitadas por crianças índias e padres jesuítas, não eram toscas apenas do ponto de vista de sua materialidade, mas também enfrentavam dificuldades relacionadas ao próprio processo de ensino e aprendizagem organizado pelos padres. A principal delas relacionava-se ao instrumental linguístico que possibilitaria a propagação dos va-

2 O padre Diego Laynes sucedeu a Inácio de Loyola na condição de prepósito-geral da Companhia de Jesus (1558-1565). Além disso, participou do Concílio de Trento (1545-1563) como teólogo dos seguintes papas: Paulo III, Júlio III e Pio IV.

3 Sobre as "matérias que os Nossos devem estudar", as Constituiçôes... prescreviam: “[...] são de muito proveito os estudos humanísticos de várias línguas (A), a lógica, a filosofia natural e moral, a metafísica, a teologia escolástica e positiva (B), e a Sagrada Escritura, serão estas as matérias que hão de estudar os que se enviam aos colégios (C). Insistirão com maior diligência naqueles que mais se relacionam com o fim indicado, tendo em conta as circunstâncias dos tempos, lugares, pessoas etc., como parecer oportuno [...]" (Companhia de Jesus, 1997, p. 129). 
lores religiosos do cristianismo católico entre os "bárbaros da terra", já que os inacianos ainda não dominavam a língua-mãe do grande tronco étnico tupi-guarani que habitava o litoral leste brasílico. As consequências pedagógicas advindas desse obstáculo só foram superadas depois que os jesuítas gramaticaram a língua tupi, tarefa iniciada por Juan Azpilcueta Navarro ${ }^{4}$ e concluída por José de Anchieta. ${ }^{5}$

Ocupando centralidade no "plano colonizador" propugnado por Manuel da Nóbrega, ${ }^{6}$ as casas de bê-á-bá, embriões dos futuros colégios jesuíticos e lócus irradiadores da cultura cristã, estavam assentadas em dois pilares que sustentaram os propósitos metropolitanos de ocupação das matas tropicais do litoral atlântico habitado pelos ameríndios, a saber: a) desenvolvimento de uma pedagogia consubstanciada nos catecismos bilíngues (tupi e português), com base no processo de ensino e de aprendizagem mnemônico (ensino de cor, memorização), tanto das línguas quanto da própria dogmática cristã católica; b) estruturação da base material que garantiria a existência das casas de bê-á-bá por meio da organização econômica fundada no princípio da "grande plantação": terras (sesmarias doadas pela Coroa), trabalho escravo desafricanizado e agropecuária (cana-de-açúcar e gado).

Inicialmente, os jesuítas não faziam distinção entre o regime de funcionamento das casas de bê-á-bá e o dos colégios. No entanto, a partir de 1553 a situação começou a mudar. Chegava ao Brasil, trazida pelo padre Luis da Grã, ${ }^{7}$ a versão preliminar das Constituiçôes... ${ }^{8}$ da Companhia de Jesus. O documento que passaria a reger o funcionamento institucional da Ordem dos inacianos estabelecia que somente os colégios poderiam amealhar bens de raiz, ${ }^{9}$ ou seja, possuir

4 Juan Azpilcueta Navarro era de origem basca e chegou ao Brasil na Primeira Expedição (1549) de padres jesuítas liderados pelo padre Manuel da Nóbrega.

5 José de Anchieta era de origem espanhola, do arquipélago das Canárias, e chegou ao Brasil na Terceira Expedição (1553) de padres jesuítas liderados por Luis da Grã.

6 Após a morte do bispo D. Pedro Fernandes Sardinha (1556) num ritual de antropofagia praticado pelos índios caeté do norte da Bahia, o padre Manuel da Nóbrega, já na condição de provincial da Companhia de Jesus no Brasil (1555-1559), redigiu, em maio de 1558, uma carta ao provincial de Portugal, Miguel de Torres. Nela expunha o seu "plano colonizador" de ocupação das terras brasílicas e propunha, além da estruturação pedagógica e econômica das casas de bê-á-bá, duas outras ações complementares em relação aos ameríndios: a erradicação, por meio simbólico e físico, dos principais traços da cultura tupi-guarani (antropofagia, guerras, pajelança, nudez, poligamia e nomadismo), e o direito à guerra justa dos cristãos contra os "bárbaros da terra", no caso daqueles que resistissem ao processo de conversão ao cristianismo (Nóbrega, 1957, p. 447 et seq.).

7 O padre Luis da Grã veio ao Brasil liderando a Terceira Expedição de padres jesuítas, que foi composta por Braz Lourenço, Ambrósio Pires, José de Anchieta, João Gonçalves, António Blasques e Gregório Serrão (Leite, 1938a, p. 561).

8 O texto final das Constituições... da Companhia de Jesus chegou ao Brasil em 1556 e foi aprovado na Santa Sé em 1558 (Leite, 1938b, p. 416).

9 O artigo 5, capítulo II, quarta parte das Constituições..., estabelecia que: "A Companhia receberá a propriedade dos colégios com os bens temporais que lhes pertencem, e nomeará para eles um Reitor que tenha o talento mais apropriado ao ofício. Esse assumirá a responsabilidade da conservação e administração dos bens temporais [...]" (Companhia de Jesus, 1997, p. 122). 
propriedades como fonte de financiamento das suas atividades educacionais. A propósito, Paulo de Assunção, em Negócios jesuíticos, analisando a simbiose que se estabeleceu entre o espiritual e o temporal no cotidiano da Companhia de Jesus no Brasil colonial, afirmou que a importância dos colégios extrapolava o interesse cultural-religioso de propagar os valores ocidentais cristãos nas terras brasílicas. Para o autor:

Os colégios eram parte importante da estrutura de funcionamento [da Companhia de Jesus], pois thes era facultado terem propriedades. Segundo as Constituições da Companhia de Jesus, os colégios poderiam tornar-se proprietários, nomeando para a sua administração um reitor que teria como responsabilidade a "conservação e administração dos bens temporais". (Assunção, 2004, p. 239)

Assim, movido pelos princípios da legalidade, Luis da Grã passou a exigir que Nóbrega cumprisse os preceitos constitucionais e, portanto, fechasse as casas de bê-á-bá, uma vez que no texto da Magna charta jesuítica não estava prevista a possibilidade de qualquer ordenação econômica para esse tipo de prática. Nóbrega resistiu, e a partir daí as divergências doutrinárias estabelecidas entre ele e Luis da Grã foram dirimidas em seu favor em virtude da intervenção direta do padre Diego Laynes, sucessor de Loyola no comando da Companhia de Jesus.

Portanto, as casas de bê-á-bá, além de não terem sido fechadas, transformaram-se paulatinamente, durante a segunda metade do século XVI, nas celulae matres dos primeiros colégios jesuíticos do Brasil colonial. Desse modo, em 1570, antes que a primeira centúria chegasse ao fim, a colônia lusitana já contava com cinco casas de bê-á-bá - Porto Seguro, Ilhéus, São Vicente, Espírito Santo e São Paulo de Piratininga - e três colégios - Bahia, Rio de Janeiro e Pernambuco (Anchieta, 1933b, p. 405). Porém, contrariando as prescrições doutrinárias contidas nos documentos basilares da ordem fundada por Inácio de Loyola, o colégio no período colonial não era apenas um estabelecimento educacional organizado no âmbito dos ensinos ginasial e secundário, pois, após as divergências doutrinárias ocorridas entre Nóbrega e Grã, a província do Brasil ganhou a chancela de Roma para praticar também o ensino elementar, ou seja, as casas de bê-á-bá. ${ }^{10} \mathrm{O}$ organograma a seguir mostra o fluxo dos níveis de ensino no interior da estrutura curricular do colégio jesuítico do Brasil colonial.

10 Segundo José Manuel Madureira (1927, p. 391): “no Brasil, durante dois seculos, quasi exclusivamente da educação do povo a Companhia se encarregou; em todos os lugares onde residia, abria collegios, com escholas primarias, desanalphabetizando e instruindo todos aquelles a quem ensinavam o catecismo". 


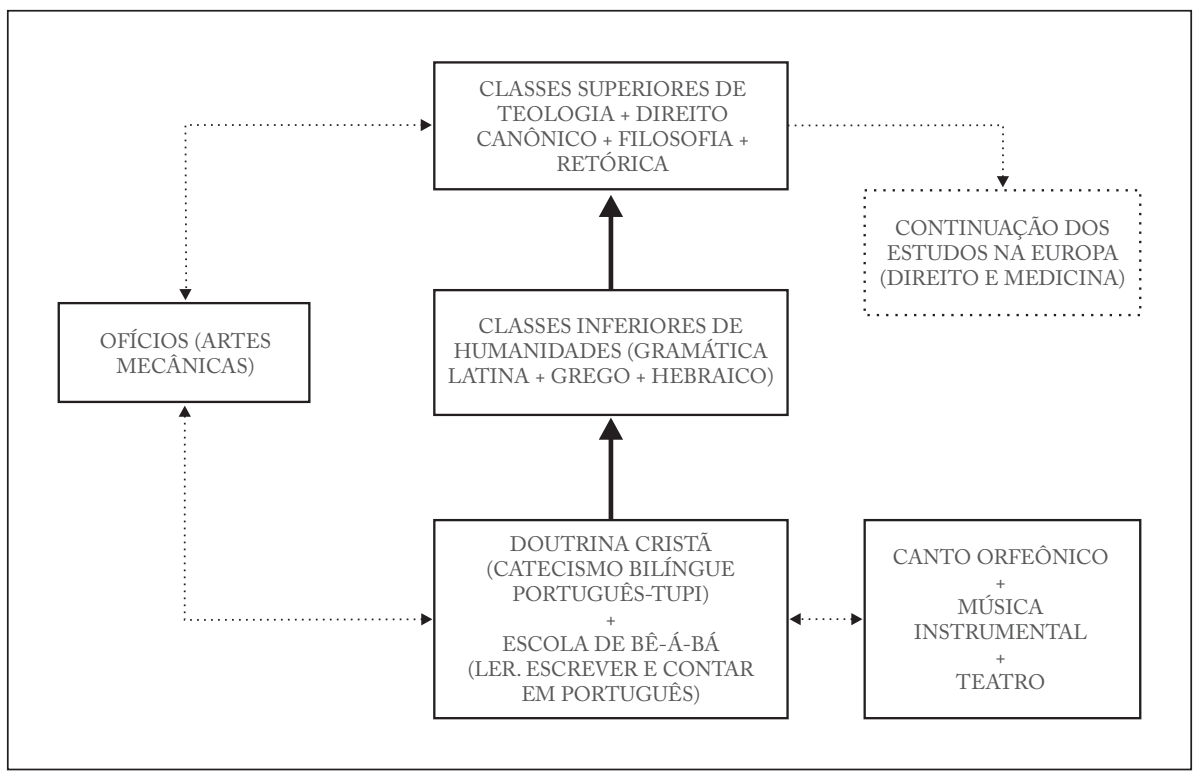

Figura 1 - Estrutura do sistema educacional jesuítico no Brasil colonial.

Fontes: Ferreira Jr.; Bittar (2004, p. 179 et seq); Bittar; Ferreira Jr. (2007, p. 51).

Elaboração dos autores.

Como ilustra o Quadro 1 a seguir, podemos considerar que o colégio da Bahia foi o caso mais emblemático da vinculação institucional entre os vários níveis de ensino: primeiras letras, ginasial e secundário. Em Salvador, fundou-se primeiramente a casa de bê-á-bá, em 1549; depois, em 1554, implantou-se o colégio segundo as normativas contidas nas Constituiçôes. Contudo, para Serafim Leite (1938a, p. 57), o colégio jesuítico de Todos os Santos nunca deixou de manter “sempre unidade moral com a casa de 1549", ou seja, a casa de bê-á-bá criada por Manuel da Nóbrega, na qual o primeiro mestre foi Vicente Rodrigues (Rijo). ${ }^{11}$ Desde a sua origem, o colégio da Bahia manteve uma base de sustentação material que financiava os seus gastos. Em 1585, além da dotação régia de "três mil ducados", a sua fazenda de gado e cana-de-açúcar era mantida pelas relações escravistas de produção com o trabalho de 150 "negros da Guiné" (homens e mulheres) e "alguns índios e índias" (Anchieta, 1933a, p. 414). Essa estrutura econômica garantia uma comunidade escolar assim constituída:

11 Vicente Rodrigues (Rijo) chegou ao Brasil na Primeira Expedição (1549) com os seguintes jesuítas: António Pires, Leonardo Nunes, João de Azpilcueta Navarro e Jácome Diogo (Leite, 1938a, p. 560). 
Quadro 1 - Jesuítas e escolásticos do colégio da Bahia em 1584

\begin{tabular}{|c|l|}
\hline \multicolumn{2}{|c|}{ Membros (jesuítas e escolásticos - número total 62) } \\
\hline Total de jesuítas & \multicolumn{1}{c|}{ Número de mestres jesuítas } \\
\hline \multirow{3}{*}{31} & $\begin{array}{l}4 \text { mestres de 4 votos (castidade, pobreza, obediência } \\
\text { e servir diretamente ao Papa) }\end{array}$ \\
\cline { 2 - 3 } & $\begin{array}{l}5 \text { mestres: 1 de teologia de consciência; } 2 \text { de } \\
\text { filosofia; 2 de latinidade (gramática) }\end{array}$ \\
\cline { 2 - 3 } & 1 mestre de bê-á-bá \\
\hline
\end{tabular}

Fonte: Anchieta (1933b, p. 395).

Elaboração dos autores.

As atividades pedagógicas desenvolvidas no colégio da Bahia, segundo José de Anchieta, provincial do Brasil (1577-1587), estavam concentradas nas seguintes classes:

[...] uma lição de teologia que ouvem dois ou três estudantes de fora, outra de casos de consciência que ouvem outros tantos e uma e outra alguns de casa, um curso de artes que ouvem dez de fora e alguns de casa, escola de ler, escrever e contar que tem até setenta rapazes filhos dos Portugueses, duas classes de humanidades, na primeira aprendem trinta e na segunda quinze escolares de fora e alguns de casa. (Anchieta, 1933a, p. 415)

No tocante ao colégio de Pernambuco, em sua "Informação da província do Brasil para nosso padre",Anchieta (idem, p.411) relata que era provido por "mil ducados que thes há dotado el-Rei D. Sebastião"e tinha "algumas cabeças de bois e vacas que se sustentam, por não haver matadouro na vila, e se assim não o fizessem, não teriam que comer”. As suas atividades pedagógicas, em contrapartida, estavam organizadas em razão de "uma classe de gramática que ouvem até 12 estudantes de fora, e também [...] escola de ler e escrever, que terá até 40 rapazes, filhos de portugueses" (idem, p. 412). Essas transcrições evidenciam que, nos colégios, a composição social dos alunos mudara, pois os filhos de portugueses já aparecem em número expressivo, diferentemente das casas de bê-á-bá, que abrigavam apenas crianças índias e mamelucas, além dos órfãos de Portugal.

Quanto à fazenda que sustentava o colégio do Rio de Janeiro, José de Anchieta (idem, ibidem) a descreveu do seguinte modo:

[...] tem duas léguas de terra em quadro das melhores da terra: nelas se fazem mantimentos e roçaria e residem os escravos e Índios da casa que são mais de 100, de Guiné e Índios da terra com suas mulheres e filhos, e uma igreja em que thes ensinam a doutrina cristã, e destes a maior parte granjeiam aquela fazenda e outras que têm a sete léguas da cidade, que é muito maior e mais fértil, de três léguas em largo e quatro para o sertão, e outros são carpinteiros, carreiros, etc. Vivem dos nossos neste Colégio de ordinários 24: 10 Padres e os demais Irmãos. Tem de renda 2.500 cruzados que lhe dotou El-Rei D. Sebastião para 50, e os 2.000 se pagam na Baía ainda que mal e tarde, e os quinhentos na Capitania do Espírito Santo, e com esta renda e com a roçaria que hei dito, e com algumas cabeças de bois e vacas que têm de sua criação, se sustentam muito bem e aos escravos que tem, e ajudam as residências ao Colégio anexas. 
Assim sendo, podemos dizer que os colégios jesuíticos do século XVI nasceram no interior das fazendas de cana-de-açúcar (engenho) e de criação de gado, cuja estrutura arquitetônica foi assim descrita por Lúcio Costa (1945, p. 13):

O programa das construções jesuíticas era relativamente simples. Pode ser dividido em três partes, correspondendo cada uma destas a uma determinada utilização: para o culto, a igreja com o coro e a sacristia; para o trabalho, as aulas e oficinas [colégio]; para residência, os "cubículos", a enfermaria e mais dependências de serviço, além da "cerca", com horta e pomar.

Essa configuração foi desenvolvida para os principais colégios jesuíticos do Brasil colonial do século XVI - como já citado, localizados na Bahia, Rio de Janeiro e Pernambuco -, bem como para os que foram criados depois. ${ }^{12}$ No entanto, na mesma proporção em que a Companhia de Jesus se transformava em grande proprietária de terras (fazendas de gado e cana-de-açúcar) e escravos, os prédios das igrejas, colégios e residências ficavam mais sólidos. Com o avanço do processo colonizador, eles foram transformando-se em baluartes da cultura ocidental cristã entre a população colonial e, ao mesmo tempo, em instituições formadoras dos próprios quadros inacianos que deveriam divulgá-la e reproduzi-la. Analisando a proposta pedagógica contida no plano de estudos da Companhia de Jesus, o padre Leonel Franca (1952a, p. 80), na "Introdução" que elaborou para edição publicada em 1952, assim se referiu ao objetivo educacional máximo ministrado nos colégios mantidos pela Ordem dos jesuítas:

O alvo a que mira a formação do Ratio - nisto em concordância incontestada com o ideal do século XVI - é a eloquência latina: ad perfectam informat eloquentiam. Levar o aluno a exprimir-se de maneira irrepreensível na linguagem de Cícero é o termo a que se subordinam todas as séries sabiamente graduadas do currículo. A gramática visa à expressão clara e correta; as humanidades, a expressão bela e elegante; a retórica, a expressão enérgica e convincente.

A propósito, as Constituições... (Companhia de Jesus, 1997,p.129) declaravam que "são de muito proveito os estudos humanísticos de várias línguas", além da lógica, filosofia natural e moral, metafísica, teologia escolástica e Sagrada Escritura, como matérias que deviam ser estudadas. Quanto ao Ratio studiorum, para admitir novos candidatos, exigia a proposição de "algumas frases para se verterem em latim, ou, se for mister, para traduzirem de algum autor clássico” (Companhia de Jesus, 1952, p. 169).

Portanto, o ideal pedagógico era formar alunos para o pleno domínio das artes liberais (humanidades) por meio da língua latina. Tal vocação estava ligada ao contexto histórico em que transcorreu a formulação do Ratio studiorum, isto é, o convulsionado século XVI das reformas religiosas. Foi então que a educação fundada nas chamadas humanidades (história, poesia, geografia, política etc.), com base nas obras filosóficas e literárias do período clássico greco-romano (Virgílio, Horácio, Cícero, Luciano, Ovídio e outros), consolidou o

12 Quando da expulsão da Companhia de Jesus do Império português, em 1759, o Brasil colonial possuía 24 colégios jesuíticos (Leite, 1950, p. 60-61). 
latim como a língua oficial da cristandade fiel ao papado num duplo sentido: língua sagrada do catolicismo apostólico romano, mantendo fidelidade à versão bíblica denominada Vulgata latina ${ }_{13}^{13}$ e língua do humanismo renascentista. Historicamente, as línguas principais em uso pelos povos que aderiram ao cristianismo desde a sua origem foram o aramaico, o grego, o siríaco, e depois o latim. Este acabou por substituir o grego a partir dos séculos III e IV, permanecendo por longos séculos a língua da cultura e da igreja romana enquanto deixava, progressivamente, de ser compreendido pela maioria dos fiéis. No século XVI, quando a cristandade se fragmentou, os reformadores passaram a empregar, nas celebrações litúrgicas, as línguas faladas nos estados nacionais, ao passo que na Igreja, que permaneceu fiel ao papado de Roma, o Concílio de Trento (1545-1563) manteve o uso quase exclusivo do latim. A reverência a essa língua pode ser compreendida considerando a sua própria origem. Segundo Vicenzo Loi (2002, p. 809-810), o latim cristão caracterizou-se

pelos fenômenos lexiográficos (hebraísmos, helenismos, neologismos formados com processos normais de sufixação latina), semânticos e sintéticos, peculiares à linguagem das comunidades cristãs do Ocidente, do século II ao V, fenômenos que apareceram e se firmaram no contexto comunitário da vida de um grupo religioso, caracterizado também linguisticamente por efeito da própria disciplina e da própria doutrina em relação à sociedade pagã.

Os aspectos disciplinares e doutrinários tornam compreensível a obediência do Ratio studiorum às diretrizes do mencionado concilio, como também explicam a razão de o ensino jesuítico estar empenhado no conhecimento e prática do latim, fazendo com que os seus colégios estivessem em "concordância incontestada com o ideal do século XVI", conforme escreveu Leonel Franca. Criados com o intuito de formar os quadros intelectuais (internos e externos) que se empenhariam para recolocar a Igreja católica no centro da comunidade cristã mundial, os colégios jesuíticos pautaram-se por uma educação de rígida disciplina intelectual, cujos conhecimentos estavam solidamente assentados na tradição cultural engendrada historicamente pelo helenismo. Desse modo, o currículo emanado do Ratio studiorum conferia aos colégios da Companhia de Jesus uma base de conhecimentos fundados nos conteúdos canônicos das disciplinas denominadas humanidades latinas.

Antes de cursar filosofia, estudos da Bíblia e da patrística, direito eclesiástico, direito moral e teologia, os alunos dos colégios jesuíticos frequentavam as classes (inferiores e superiores) de humanidades e retórica como requisito necessário para o domínio da arte do falar em latim e nas línguas vernáculas de forma substantiva e eloquente. Isso porque o objetivo era que aprendessem a pregar a dogmática cristã tridentina e, quanto ao âmbito do mundo secular, se preparassem para a arte de governar. Serafim Leite, nos dez tomos da obra História da Companbia de Jesus no

13 Em 383 d.C., por recomendação do papa Dâmaso, São Jerônimo (347-419 d.C.) iniciou a tradução de vários livros, tanto do Antigo quanto do Novo Testamento, diretamente do grego e do hebraico, que, depois reunidos em um único livro, transformaram-se na chamada Vulgata latina (Pisano, 2004, p. 1.753-1.754). Ela teve uma importância capital para a liturgia e teologia católica, pois foi a Bíblia que se tornou autoridade na Igreja católica apostólica romana desde o Concílio de Trento (1545-1563) até a publicação, em 1979, da Nova vulgata. 
Brasil, apresenta tanto o currículo quanto os autores clássicos estudados nos colégios coloniais para o ensino das humanidades, conforme mostra o organograma a seguir:

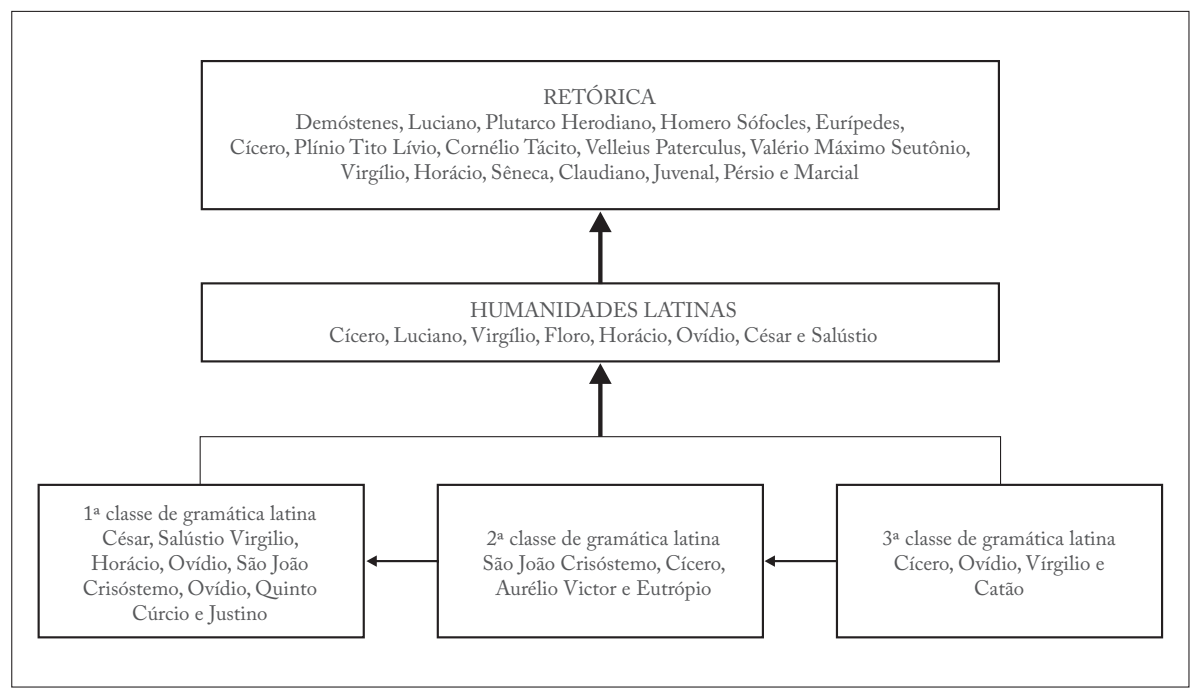

Figura 2 - Currículo de humanidades latinas e autores utilizados nos colégios jesuíticos. Fonte: Leite (1949, p. 151).

Elaboração dos autores.

Estruturada no método mnemônico de ensino e aprendizagem e na concepção de mundo da Igreja romana, a educação jesuítica visava formar quadros capazes de dominar plenamente o conjunto dos conhecimentos humanos elaborados pelos autores clássicos, desde a literatura latina helenística à dogmática cristã herdada da tradição judaica. Para o domínio desses conhecimentos, os jesuítas tinham no Ratio studiorum o instrumento pedagógico indispensável que, além disso, garantia rigor e excelência ao ensino ministrado nos seus colégios. Se considerarmos, ademais, que a Companhia de Jesus, diferentemente dos reformadores, não defendia ensino elementar para todos os meninos e meninas, além de não postular a vinculação entre formação intelectual e profissional, constataremos o caráter elitista dos seus colégios no contexto histórico do Brasil colonial. O método pedagógico praticado pelos jesuítas, por sua vez, estava assentado nos princípios herdados da universidade medieval e sistematizado da seguinte maneira:

1. Controle disciplinar rígido das normas pedagógicas estabelecidas pelo Ratio studiorum, o que era exercido pelo reitor e prefeito dos estudos;

2. Preleção dogmática, feita pelos professores, dos conteúdos canônicos dos conhecimentos curriculares (humanidades latinas, retórica, filosofia, estudos da Bíblia em hebraico, grego e latim, direito eclesiástico, direito moral e teologia);

3. Repetição (leitura por meio da memorização/aprendizagem mnemônica);

4. Disputas orais na língua latina (emulação entre grupos de alunos da mesma classe tendo como conteúdo as obras estudadas, ou seja, exercícios coletivos de fixação mnemônica dos conhecimentos por meio de perguntas e respostas); 
5. Composição (redação de textos em latim tendo com referência os temas de estudo);

6. Interrogações (questões formuladas sobre as obras clássicas estudadas);

7. Declamação (exposição oral dos conhecimentos aprendidos por meio da retórica);

8. Prática sistemática dos exercícios espirituais. (Franca, 1952b, p. 119 et seq.)

Contudo, se o emprego do método de aprendizagem mnemônica logrou pleno êxito na educação das chamadas artes liberais (ciências humanas), não podemos falar o mesmo em relação ao ensino da moderna história natural (ciências da natureza) a partir do século XVI, pois, como sabemos, a física, a química e a biologia passaram a exigir, desde então, o método empírico de investigação como fundamentação epistemológica primária para a comprovação das suas respectivas cientificidades, superando, assim, a lógica especulativa derivada da escolástica tomista. Porém, a Companhia de Jesus, depois de aprovadas as teses teológicas tridentinas, estava muito mais preocupada com a restauração da antiga ordem societária secular, na qual a Igreja católica romana havia ocupado o epicentro da universalidade religiosa, do que em empregar grandes esforços no avanço da cientificidade explicativa do mundo circundante. Para os inacianos, urgia formar homens que propugnassem pela restauração - teórica e prática - de um "reino cristão" na face da terra que fosse o mais cristão de todos os reinos até então existentes. Daí a centralidade pedagógica que as humanidades latinas, consubstanciadas no Ratio studiorum, assumiram no âmbito dos colégios jesuíticos.

\section{AS ARTES MECÂNICAS NOS COLÉGIOS JESUÍTICOS COLONIAIS}

Criada numa época marcada pela prevalência da produção de manufaturas e do comércio internacional de mercadorias em escala planetária, tempo no qual a relação entre ciência e trabalho manual se processava cada vez mais de forma orgânica, a Ordem dos jesuítas não tinha os mesmos objetivos religiosos das suas congêneres medievais. Em vez do monacato, organizado em torno da clausura voltada para a purificação e contemplação espiritual, os padres da Companhia de Jesus eram formados com base em uma rígida disciplina derivada dos exercícios espirituais, da obediência inquestionável à hierarquia eclesiástica e aos cânones teológicos escolásticos - para interferir diretamente no mundo temporal. Nisto ela foi inovadora. Entretanto, a vida naquele século impunha condições de existência diferentes daquelas gozadas nos monastérios medievais regulados pelos calendários litúrgicos, pois, para "estar no mundo" e pôr em prática o processo evangelizador dos chamados gentios ou da reconversão dos próprios cristãos, era preciso organizar uma sólida base material de existência; caso contrário, o projeto catequético não lograria êxito.

Assim, para sobreviver no âmbito societário condicionado pelas relações mercantis de produção, ou seja, de produção e circulação de mercadorias, a Companhia de Jesus, baseada nas próprias Constituições..., estabeleceu como estratégia de atuação adquirir e manter propriedades produtoras de manufaturas com o objetivo de financiar os seus colégios espalhados mundo afora. Mas, no contexto das terras brasílicas, quais eram os tipos de "oficiais mecânicos" responsáveis pela produção de mercadorias nas 
unidades econômicas da Companhia de Jesus? Os indícios para se responder a tal questão encontram-se nas páginas escritas pelo padre Serafim Leite. O historiador oficial da Companhia de Jesus, na sua obra Artes e ofícios dos jesuitas no Brasil (1549-1760), assim classificou os "ofícios mecânicos" praticados desde os primórdios da colonização lusitana:

Os ofícios mecânicos entraram no Brasil com os portugueses, primeiro nas vilas dos donatários, e logo, mais abundantes, ao fundar-se o Estado do Brasil em 1549. Na armada que levou Tomé de Sousa e Nóbrega chegaram todos os elementos necessários à administração e defesa do novo Estado e a construção de sua capital que se ia erguer ali, onde antes não havia senão matas e algumas cabanas de palha. Com os jesuítas e os homens da administração civil e militar, assinala-se a presença dum médico (físico-cirurgião), dum arquiteto e dum mestre de obras, e contam-se numerosos pedreiros, carpinteiros, serradores, tanoeiros, ferreiros, serralheiros, caldeireiros, cavouqueiros, carvoeiros, caeiros (fabricantes de cal), oleiros, carreiros (fabricantes de carros), pescadores, construtores de bergantins, canoeiros, e até um barbeiro e um encadernador. (Leite, 1953, p. 27)

Assim, após listar os primeiros "ofícios mecânicos" executados no Brasil colonial, Serafim Leite passa a relatar como a própria lógica de expansão das propriedades pertencentes à ordem fundada por Inácio de Loyola - fazendas, igrejas, colégios e residências - condicionava a crescente demanda pelas artes mecânicas:

Como se sabe, os padres da Companhia de Jesus, da Assistência de Portugal, tiveram colégios, residências e fazendas desde o Amazonas ao Rio da Prata e da costa atlântica ao Mato Grosso. Muitas das casas e igrejas não existem hoje. Mas ainda as há de pé, nos estados do Pará, Maranhão, Ceará Pernambuco, Sergipe, Baia, Espírito Santo, Rio de Janeiro, São Paulo, e Paraná. As que chegaram à atualidade quase todas as vimos pessoalmente e são hoje monumentos nacionais classificados. Outras igrejas foram reconstruídas quer ainda no tempo dos jesuítas quer depois. Mas das que não existem, ter-se-á perdido tudo? Deve-se ter presente que ao construir-se uma igreja, nunca se destrói o recheio da anterior, naquilo que tem de útil, sobretudo o que é prata e oiro e arte móvel, nos sectores de pintura, estatuária, mercearia fina: quadros, imagens, credencias, sacras, tocheiros, retábulos, e às vezes altares interiores, como é patente na igreja de Embu (Mboi), São Paulo. (idem, p. 32)

Das propriedades jesuíticas, eram as fazendas as que mais requisitavam "artes mecânicas". Para manter em plena atividade a produção econômica derivada da agropecuária (açúcar, couro e carne de gado), cuja comercialização resultava na principal fonte de financiamento das atividades educacionais jesuíticas, as fazendas da Companhia de Jesus se viam na contingência de manter oficinas que fabricavam as mercadorias necessárias ao seu consumo. Enquanto a atividade econômica da agropecuária era mantida com base na mão de obra escrava usada em larga escala, inicialmente indígena, depois africana, as manufaturas eram produzidas mediante processos artesanais semelhantes àqueles utilizados nas corporações de artes e ofícios medievais. Tratava-se de um processo produtivo que já exigia a aplicação de deter- 
minados conhecimentos científicos e uma incipiente especialização do trabalho, cuja formação se aproximava da escola, embora continuasse a se "distinguir da escola pelo fato de não se realizar em um 'lugar destinado a adolescentes', mas no trabalho, pela convivência de adultos e adolescentes", ou seja, não era propriamente uma "escola do trabalho, pois o próprio trabalho era a escola, pois somente se acrescentava ao mesmo os aspectos intelectuais" (Manacorda, 1989, p. 161-162).

Mas como se originou essa espécie de "escolas do trabalho" no contexto da educação jesuítica colonial? As primeiras referências estão associadas às próprias demandas surgidas durante a construção das casas de bê-á-bá e dos colégios. Em carta de 1549, endereçada a Simão Rodrigues, provincial da Companhia de Jesus em Portugal, o padre Manuel da Nóbrega (1956a, p. 119) assim se referia à ausência de carpinteiros para a construção de edificações: "a terra não oferece facilidade para contratar oficiais mecânicos”. Portanto, foram as próprias condições materiais de existência encontradas pelos padres jesuítas que impuseram a necessidade de se criar oficinas de artes mecânicas desde os primeiros momentos da sua atuação nas terras brasílicas. A propósito, o padre António Pires, em carta expedida de Pernambuco, em agosto de 1551, relatava aos irmãos de Coimbra a dificuldade dos jesuítas para encontrar trabalhadores que produzissem as manufaturas consumidas nas suas propriedades:

en esta tierra, por la falta que ay de officiales, la necessidad nos haze aprender todos os offícios, porque yo os digo que, por los offícios que en esta tierra tengo aprendidos, poderia ya bivir. Christo nuestro Señor nos haga bien aprender y obrar el offício de la perfección, para que nuestros trabajos y servicios le sean aceptos. (Pires, 1956, p. 264)

Assim, em decorrência da absoluta ausência de "oficiais" na "terra dos papagaios", os jesuítas tiveram de aprender com "perfeição", desde o início do processo evangelizador, as artes mecânicas essenciais ao projeto de construção do conjunto de edifícios que ocupava centralidade arquitetônica nas fazendas de gado e cana-de-açúcar: a igreja, o colégio, a residência dos padres e as próprias oficinas de artes mecânicas. Sem esquecer, obviamente, do próprio complexo produtivo formado pelos edifícios dos estábulos, engenhos de açúcar e moradias dos escravos.

$\mathrm{O}$ exame das fontes utilizadas nesta pesquisa permite observar que na mesma proporção em que cresciam numericamente as fazendas pertencentes à Companhia de Jesus, ${ }^{14}$ multiplicava a demanda por "oficiais mecânicos" em decorrência das atividades econômicas cotidianas desenvolvidas no âmbito das suas propriedades agrárias. Inseridas, social e economicamente, em um contexto marcado pelas relações escravistas de produção e pela escassez de "oficiais" livres, a alternativa encontrada pelos jesuítas, a fim de atender à necessidade de mão de obra que produzisse manufaturas, foi criar as oficinas de artes mecânicas especializadas anexas aos colégios. Ou como afirmou Serafim Leite (1938b, p. 591-592):

14 Serafim Leite (1950, p. 88-93), em História da Companbia de Jesus no Brasil, afirma que a Ordem inaciana possuía em 1759, quando da sua expulsão dos domínios imperiais portugueses, 359 fazendas espalhadas pelo imenso território colonial brasileiro. 
Com o desenvolvimento e correspondentes necessidades dos colégios, começaram a aparecer, nas oficinas anexas, os encarregados dos engenhos, os praticantes de cirurgia, os artífices especializados em ourivesaria e até em estatuária, ainda que geralmente as esculturas finas vinham de afamados estatuários de Lisboa. Mencionamos ainda o ofício de enfermeiro, que às vezes era na realidade farmacêutica e tomou vulto no decorrer do tempo.

Essas oficinas anexas aos colégios eram unidades que fabricavam manufaturas com base nas relações de produção entre um mestre e os aprendizes da ocupação manual ou mecânica. O processo de ensino e aprendizagem transcorria tal como nas corporações de ofício medievais, ou seja, envolvendo diretamente os padres jesuítas e os escolásticos dos colégios durante o trabalho produtivo das manufaturas. A aprendizagem decorria da observação e imitação, ou seja, no próprio processo de fazer as manufaturas. Pela força das circunstâncias, os missionários tiveram de se tornar também mestres de ofícios e montar oficinas, que acabaram por estar organicamente vinculadas às fazendas, conforme descreveu Celso Suckow da Fonseca (1961,p.15-16):

Com o correr do tempo, os padres organizaram as suas plantações, dando-lhes notável desenvolvimento, chegando, mesmo, a serem elas as maiores e mais produtivas do Brasil. Aquelas instâncias tornaram-se verdadeiras escolas de indústria, onde os colonos, que eram índios, aprenderam os melhores métodos de cultivar a terra, de construir casas, estradas e obras de arte, assim como a beneficiar o couro, ou fabricar o açúcar, que era abundante. $\mathrm{E}$ como havia poucos artífices, os missionários foram também mestres de ofícios, formando numerosos discípulos nas artes de tecelagem, de carpintaria, de ferraria ou da sapataria. Chegaram, mesmo, a montar oficinas de certo vulto, destinadas a fornecer os elementos de que necessitavam os engenhos e a lavoura, ministrando nelas, que se achavam a muitas léguas, sertão a dentro, os rudimentos das profissões manuais, que os silvícolas aprendiam facilmente.

Essa simbiose manifesta entre fazendas e oficinas de artes e ofícios anexas aos colégios já estava exposta nas cartas jesuíticas desde a segunda metade do século XVI, como a de junho de 1553, de Manuel da Nóbrega ao padre Luís Gonçalves da Câmara, futuro preceptor e confessor do rei D. Sebastião I (1557-1578). Nela, ele já relatava as medidas que tinham sido tomadas para enfrentar as dificuldades relativas à carência de "oficiais mecânicos". Nóbrega (1956b, p. 503) afirma também que havia mandado "enseñar algunos moços de la tierra para sertón a ferreiros e a tesselóes, y de allá devian de mandar dos niños huérfanos enseñados a officiaes para acá, porque esto hallamos ser en esta tierra una gran parte para la conversión destos infieles".

Outro encaminhamento prático adotado para formar artesãos necessários às demandas por "ofícios mecânicos" encontra-se numa carta redigida em 1554 pelo padre Luís da Grã (1957, p. 136) ao padre Inácio de Loyola, o geral da Companhia de Jesus em Roma, explicando que:

destos moços puse a deprender officios quatro o cinquo, y esto se a de hazer com los otros, sino que no há aqui officios que les armen, y son ellos de tal 
condición que, si les diere el maestro, irse na luego: que en casa tenemos mucho trabajo acerca de su castiguo, porque sin castiguo no se hará cosa.

Como se nota, a carta menciona os castigos, no entanto, essa prática não se restringia ao método de ensino mnemônico adotado na aprendizagem das humanidades latinas, mas era adotada também nas oficinas de artes mecânicas. Essas, por sua vez, tenderam a crescer com a consolidação da própria lógica econômica colonial que possibilitou historicamente o alargamento das propriedades agrárias pertencentes à Companhia de Jesus. A esse respeito, o padre jesuíta Serafim Leite, na já citada obra Artes e ofícios dos jesuitas no Brasil, elaborou o seguinte rol de "ofícios mecânicos" praticados no interior dos colégios da Companhia durante o período colonial:

Tabela 1 - Classificação das artes e ofícios dos jesuítas no Brasil

\begin{tabular}{l|l}
\hline \multicolumn{2}{c}{ Artes e ofícios de construção } \\
\hline Arquitetos e mestres de obras & $\begin{array}{l}\text { Carpinteiros, entalhadores, embutidores, } \\
\text { marceneiros, tanoeiros, torneiros e serradores }\end{array}$ \\
\hline Pedreiros, canteiros e marmoreiros & Construtores navais \\
\hline Ferreiros, serralheiros e fundidores & Belas-artes \\
\hline \multicolumn{2}{c}{} \\
\hline Escultores e estatuários & Cantores, músicos e regentes de coro \\
\hline Pintores e douradores & Oleiros e barristas (azulejos) \\
\hline \multicolumn{1}{c}{ Manufaturas } \\
\hline Alfaiates e bordadores & $\begin{array}{l}\text { Sapateiros (sapateiros e alpercatas, } \\
\text { artífices de sola e curtidores de peles) }\end{array}$ \\
\hline Tecelões &
\end{tabular}

\section{Ofícios de administração}

\begin{tabular}{l|l}
\hline $\begin{array}{l}\text { Administradores de engenhos e fazendas, } \\
\text { pastores, agricultores e procuradores }\end{array}$ & Salinas \\
\hline Pescarias & \\
\hline
\end{tabular}

\section{Serviços de saúde}

\begin{tabular}{l|l}
\hline Enfermeiros e cirurgiões & Boticários ou farmacêuticos \\
\hline
\end{tabular}

\begin{tabular}{l|l}
\hline \multicolumn{2}{c}{ Outros ofícios } \\
\hline $\begin{array}{l}\text { Mestres de meninos e diretores } \\
\text { de Congregação Marianas }\end{array}$ & Barbeiros e cabeleireiros \\
\hline $\begin{array}{l}\text { Bibliotecários, encadernadores, } \\
\text { tipógrafos e impressores }\end{array}$ & $\begin{array}{l}\text { Ofícios domésticos (dispenseiro, } \\
\text { porteiro, cozinheiro, roupeiro etc.) }\end{array}$ \\
\hline Pilotos & $\begin{array}{l}\text { Artes e ofícios singulares (calígrafo, } \\
\text { ourives de prata, cartógrafo, fabricante } \\
\text { de cal, químico, papeleiro etc.) }\end{array}$ \\
\hline
\end{tabular}

Fonte: Leite (1953, p. 39 et seq).

Elaboração dos autores. 
Essa ampla diversificação de ofícios ensinados e praticados no interior dos colégios pode ser entendida se levarmos em conta a longa hegemonia educacional de 210 anos (1549-1759) que a Companhia de Jesus exerceu no Brasil colonial. O rol permite compreender também que o sistema de ensino jesuítico exigia mão de obra mais qualificada conforme se tornava mais sólido e complexo. Por essa razão, começam a aparecer nos colégios ofícios mais intelectualizados, como o de bibliotecários, encadernadores, tipógrafos e impressores. Mas no começo não foi assim, além de essa variedade de "artes mecânicas" diferir em quantidade da que foi descrita por José de Anchieta em carta de 1560, ou seja, da época em que a missão inaciana se encontrava nos seus primórdios. Na relação elaborada pelo jesuíta que gramaticou a língua tupi, cujo destinatário era o padre Diego Laynes, substituto de Loyola no comando da Companhia de Jesus, encontramos um cabedal mais modesto de demandas por "oficiais mecânicos". Ei-lo:

no dexaré de dezir, pues que vino a propósito, que quase ninguna arte ay de lãs necessárias para el commún uso de la vida que los Hermanos no sepan hazer. Hazemos vestidos, çapatos, principalmente alpargates de um hilo com cáñamo, que nosotros tiramos de unos cardos echados em el água y curtidos, los quales alpargates son mui necessarios por la aspereza de las selvas, y las grandes inchientes de las aguas, las quales es necessario passar muchas vezes por grande spatio hasta la cinta y aún hasta los pechos; barbear, curar heridas, sangrar, hazer casas y cosas de barro, y otras semejentes cosas no se busca fuera, de manera que la otiosidad no tiene lugar alguno en casa. (Anchieta, 1958, p. 256)

Pela descrição do que faziam - sapatos, vestidos, casas, barbear, curar -, conclui-se que desde o início os padres jesuítas não só catequizavam os chamados "bárbaros da terra", celebravam missas, confessavam cristãos, ensinavam humanidades latinas, filosofia e teologia. Eles também praticavam e instruíam artes e ofícios nos colégios mantidos pela Companhia de Jesus, pois, segundo a carta, não havia lugar para a ociosidade. Se as primeiras atividades estavam relacionadas à missão evangelizadora que tinha como objetivo propagar a fé cristã no Novo Mundo, as segundas guardavam direta vinculação com as necessidades econômicas geradas pela administração secular dos bens materiais que iam sendo amealhados durante o largo período de 1549 a 1759. Dito de outra forma: a demanda crescente por ofícios estava condicionada ao fato de que a Ordem inaciana foi transformando-se, ao longo do tempo, em uma grande empresa mercantil ligada ao mercado internacional de circulação de manufaturas.

A partir de 1614 - em decorrência do crescimento das propriedades e, consequentemente, dos "ofícios mecânicos"-, a Companhia de Jesus passou a organizar os oficiais das "artes mecânicas" que trabalhavam nas suas fazendas, residências, colégios e igrejas. Para tanto, foi criada a "Confraria de Oficiais Mecânicos" como mecanismo de controle ideorreligioso dos trabalhadores artesanais que labutavam nas propriedades jesuíticas. A Confraria, que abrangia todos os ofícios praticados no Brasil colonial, era "constituída por artífices e homens da classe mercantil, o que a esse tempo se chamava 'plebeus'”(Leite, 1953, p. 28-30). 
No mesmo ano de 1614, o padre Henrique Gomes, provincial do Brasil (1609-1615), relatava ao padre António de Mascarenhas, assistente da Companhia de Jesus em Roma, a importância religiosa e socioeconômica da organização dos "oficiais mecânicos" que trabalhavam principalmente nos colégios da ordem, já que a:

Confraria dos Oficiais Mecânicos, que há pouco se instituiu em este colégio [Bahia] e no de Pernambuco, em ambos teve bons princípios e vai com igual aumento, ainda que o diabo parece começou logo a prever ou sentir já o bem de tal obra, e, por meio de gente pouco considerada, a quis encontrar, desautorizando-a com títulos de confraria de vilões ruins; porém saiu-lhe ao revés sua pretensão, que isso mesmo excitou a muitos a aceitarem e virem pedir com instância, antes não faltaram, dos mais honrados, alguns que fizessem muita por serem admitidos, e vendo se lhes fechavam as portas com dizer era confraria somente de oficiais, replicaram que também o eram, alegando por si serem senhores de engenho, título que em outras ocasiões alegam para se enobrecerem, como em feito os tais são, pela maior parte, os grandes do Brasil. A de Pernambuco, me escreveram agora, ir mui florente e passaram os confrades já de cento; aqui, são mais de 80. (Leite, 1945, p. 10-11)

Mas, além dos chamados “oficiais mecânicos plebeus", quais foram os outros ofícios praticados ou ensinados pelos padres jesuítas coloniais? ${ }^{15}$ De acordo com as fontes documentais, podemos considerar como os mais significativos os nomes e ofícios que se seguem: João Filipe Bettendorff (1625-1698), reitor do Colégio de São Luís do Maranhão e autor da obra Crônica da missão dos padres da Companbia de Jesus no Maranhão, era arquiteto e construtor de igrejas; Alexandre de Gusmão (1629-1724), provincial do Brasil (1684-1688) e autor da Arte de criar bem os filhos na idade da puerícia, praticou a carpintaria; Juan de Azpilcueta Navarro (....-1650), autor dos primeiros catecismos bilíngues (português e tupi), cantava e regia coros compostos por curumins; Belchior Paulo (1554-1619), foi professor de ler e escrever no Colégio das Artes da Universidade de Coimbra e adornou com pinturas casas, colégios e igrejas da Companhia no Brasil (Baía/1589, Espírito Santo/1598, Rio de Janeiro/1600, Santos/1606, São Paulo de Piratininga/1616); José de Anchieta (1543-1597) exerceu os ofícios de sapateiro, fabricava alpercatas, e de enfermeiro; Salvador Pereira (1626-1700) foi missionário fazendeiro, administrador de engenhos de açúcar e fazendas de gado; Francisco da Silva (1695-1763) foi boticário e escreveu tratados da Farmacopeia brasileira no Colégio de Olinda; Francisco de Pontes (1614-1675) era alfaiate de ofício e conhecido como o "alfaiate santo", em virtude das profecias que fazia; e Pedro Pereira (1651-1726), que exerceu a superintendência da cozinha do Colégio do Rio de Janeiro (Leite, 1953, p. 39 et seq.).

Os casos aqui citados nos fornecem uma compreensão da imbricação entre artes liberais e artes mecânicas na vida cotidiana dos colégios jesuíticos coloniais, ou

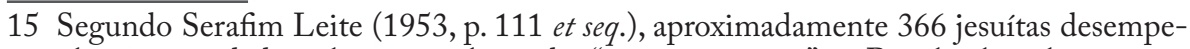
nharam atividades relativas às chamadas "artes mecânicas" no Brasil colonial. 
seja, inacianos que eram ao mesmo tempo professores de artes liberais (humanidades latinas, retórica, filosofia e teologia) e operários de artes mecânicas (os mais variados ofícios praticados no interior das fazendas-colégios da Companhia de Jesus). Assim sendo, podemos concluir que as fazendas-colégios eram lócus autossuficientes, quer na irradiação dos valores culturais da chamada "civilização ocidental cristã", quer na produção da base material de existência. Essa base material era garantida por um trabalho mais especializado operado pelos jesuítas, que se valiam, em larga escala, do trabalho escravo na fabricação de manufaturas artesanais e demais produções necessárias ao funcionamento dos colégios e fazendas. Ou seja, diferentemente do que ocorria nas corporações de ofício da Europa ocidental na mesma época, aqui, em decorrência do modo de produção escravista, em vez de aprendizes e jornaleiros, isto é, os que trabalhavam por jornada, a maior parte da mão de obra nas oficinas de artes mecânicas era escrava. Tal fato - o de não ser necessária a formação de uma mão de obra assalariada no Brasil colonial - explica a razão de a instrução dessas artes ter sido complementar à de humanidades, não merecendo, portanto, a mesma importância desta.

\section{CONCLUSÃO}

As fontes consultadas neste estudo permitiram-nos descobrir na ação pedagógica da Companhia de Jesus práticas semelhantes ao que hoje chamaríamos de ensino profissional, ou seja, um rol de atividades necessárias ao funcionamento dos seus colégios e fazendas: as artes e ofícios ensinados pelos padres. Como mostramos, elas foram complementares e secundárias comparativamente ao ideal formativo professado pelos jesuítas e, desse modo, colocam em questão o histórico preconceito que marcou o início da história da educação no Ocidente. Isso porque, desde a Grécia Antiga, o ideal de formação humana, conforme a concepção homérica, ficou caracterizado por dois momentos distintos: na juventude, a arte do fazer; na velhice, a arte do falar. No contexto de uma sociedade escravocrata, os dois momentos que formariam o "homem completo" se realizariam somente nos indivíduos da classe dominante, os quais deviam exercer a guerra enquanto jovens (arte do fazer) e se preparar para governar a pólis na velhice (arte do falar). Segundo a concepção platônica, a educação dos homens livres deveria obedecer a um único objetivo: a sua própria cultura. $\mathrm{O}$ mesmo princípio foi preconizado por Aristóteles (384-322 a.C.), que distinguiu o que se faz para a utilização (razão prática) do que se faz para o conhecimento (razão teórica). Para ele, qualquer educação com finalidade prática era indigna dos homens livres, tal como escreveu:

Agir em vista de si mesmo ou dos amigos ou por amor à virtude é digno de um homem livre; mas, quem faz essas mesmas coisas para os outros, muitas vezes parecerá que está agindo de maneira servil e mercenária. Os ramos de ensino atualmente em voga têm então esta dupla tendência. (Aristóteles, 1988, p. 267-268) 
O ideal de formação grega, a paideia, foi assimilado pelos romanos a partir do século III a.C., no decorrer do processo de aculturação de Roma pela Grécia vencida. Ou seja, os vencidos acabaram por impor sua cultura aos rudes conquistadores. No entanto, a tradição bélica dos romanos radicalizou esse princípio, e Cícero (106-43 a.C.), embora repetisse as mesmas argumentações de Aristóteles, distinguindo as profissões liberais das indignas, não reconhecia nem nas primeiras alguma dignidade civil. Aos cidadãos romanos cabia exclusivamente governar os povos com leis firmes, ou seja, o seu ofício era exclusivamente o de ser cidadão.

A escola cristã no Ocidente medieval herdou a repulsa às atividades manuais tão logo começaram a se formar as primeiras ordens religiosas para atuar nos cenóbios. Ao tratar da Regula benedicti, que no ano 540 reelaborou regras do monasticismo ocidental, Manacorda relata que, mesmo diante das necessidades objetivas de sobrevivência nos mosteiros, os monges "ficavam tristes" quando eram solicitados a trabalhar manualmente, sendo então preciso confortá-los com "uma razão moral" (Manacorda, 1989, p. 117).

Resistindo ao tempo, essa tradição, fortalecida pelos mil anos de medievalismo ocidental cristão, chegou à escola do século XX e foi analisada por Gramsci em seus anos de cárcere sob o fascismo, quando elaborou a necessária crítica à separação mecânica entre instrução e educação:

Não é completamente exato que a instrução não seja também educação: a insistência exagerada nesta distinção foi um grave erro na pedagogia idealista [...]. Para que a instrução não fosse igualmente educação, seria preciso que o discente fosse uma mera passividade, um "recipiente mecânico" de noções abstratas, o que é absurdo, além de ser "abstratamente" negado pelos defensores da pura educatividade precisamente contra a mera instrução mecânica. (Gramsci, 2000, p. 42-43)

Chegando aos nossos dias, Antonio Rugiu (1998, p. 2) considerou que:

a história da pedagogia ou da educação quase nunca tratam do artesanato e de sua importância formativa, elas também submissas ao princípio segundo o qual a educação diz respeito somente a quem se forma através dos livros. Mas deste modo continua-se a perpetrar uma injustiça histórica, cancelando um traço sobre o qual caminhou grande parte da juventude, desde a infância do homem que havia há pouco tempo aprendido a viver em sociedade.

Concordando com a análise de Rugiu, Luiz Antônio Cunha (2005) também criticou os intelectuais que acreditam ser a verdadeira educação somente aquela que se assimila por meio dos livros e escutando a voz do mestre, nas carteiras das escolas ou das universidades. Dando razão à crítica do autor, cremos que este artigo contribui para a pesquisa da história da educação, desvelando aspectos do ensino manual ministrado pelos padres da Companhia de Jesus, uma vez que no contexto da colonização brasileira, baseada na escravidão, ficou reforçado o valor da educação intelectual e o desprezo por qualquer ensino manual, já que esse era associado a 
atividades de escravos. Celso Suckow da Fonseca, em História do ensino industrial no Brasil, chega a afirmar que, nas fazendas, quando a aprendizagem caseira dos ofícios passou a ser ministrada aos escravos, o ensino dos ofícios se abastardou.

A Companhia de Jesus foi criada em 1540 e a sua fundação ficou vinculada ao fato histórico de que foi exatamente o século XVI a matriz das duas principais concepções pedagógicas que marcariam a educação dos séculos seguintes na Europa. A primeira delas foi a concepção reformadora enraizada nas prédicas luteranas sobre a obrigatoriedade escolar e necessidade de aliar ensino intelectual à instrução profissional. Quanto à segunda, foi a contrarreformista, emanada da Igreja católica e professada pela Companhia de Jesus, que manteve os traços essenciais da concepção humanística tradicional, com ênfase no ensino de textos clássicos permitidos pela Santa Sé. Com base nessa compreensão, tornou-se comum a crítica segundo a qual o ensino jesuítico no Brasil teve caráter livresco, assertiva com a qual estamos de acordo, embora não subscrevamos qualquer tendência pedagógica que rejeite o aprendizado por meio de livros.

Com os dados de que dispúnhamos, foi possível mostrar que os colégios jesuíticos não foram apenas "fortificações" da cultura ocidental cristã no interior da colônia lusitana situada nos trópicos americanos. Eles foram também locais de aprendizagem de artes mecânicas que instruíam, com frequência, os oficiais destinados a operar o funcionamento dos engenhos de açúcar, planejar a arquitetura e construir igrejas e colégios. Consequentemente, evidenciamos que o ensino jesuítico não foi exclusivamente livresco, e que a hegemonia educacional exercida pela Companhia de Jesus variou de acordo com as circunstâncias históricas que permearam a lógica colonial metropolitana, adquirindo aspectos de improvisação e adaptação ao meio.

De todo modo, os dados aqui presentes ratificam o predomínio das humanidades no conjunto das ações pedagógicas da Companhia de Jesus no Brasil. Ao revelarmos aspectos do ensino de artes e ofícios nesse sistema, mostramos também que eles exerceram papel complementar e secundário àquelas. Por isso, embora seja corrente o entendimento segundo o qual a educação nos colégios jesuíticos tenha se pautado exclusivamente pelas artes liberais, este artigo mostrou que não se deve dissociar delas o estudo das artes mecânicas.

\section{REFERÊNCIAS}

Anchieta, José de. Informação da província do Brasil para nosso padre (1585). In: . Cartas, informações, fragmentos históricos e sermões (1554-1594). Rio de Janeiro: Civilização Brasileira, 1933a. p. 409-447.

Breve narração das coisas relativas aos colégios e residências da Companhia nesta Província Brasílica, no ano de 1584. In: __ Cartas, informaçôes, fragmentos históricos e sermões (1554-1594). Rio de Janeiro: Civilização Brasileira, 1933b. p. 395-408.

. Carta do Ir. José de Anchieta ao P. Diego Laynes (São Vicente, 1 de junho de 1560). In: Leite, Serafim (Org.). Cartas dos primeiros jesuitas do Brasil (1558-1563). Coimbra: Tipografia da Atlântida, 1958, t. III, p. 246-269. 
Aristóteles. Política. 2. ed. Tradução, introdução e notas de Mário da Gama Kury. Brasília: Editora da UnB, 1988.

Assunção, Paulo de. Negócios jesuíticos: o cotidiano da administração dos bens divinos. São Paulo: EDUSP, 2004. 506 p.

Bettendorff, João Felipe. Crônica da missão dos padres da Companhia de Jesus do Maranhão. 2. ed. Belém: Secretaria de Estado da Cultura (SECULT), 1990.697 p.

Bíblia Sagrada. A Bíblia de Jerusalém. 7. impr. São Paulo: Sociedade Bíblica Católica Internacional \& Paulus, 1995.

Bittar, Marisa; Ferreira Jr., Amarilio. Casas de bê-á-bá e colégios jesuíticos no Brasil do século 16. Em Aberto, Brasília, INEP, v. 21, n. 78, p. 33-57, dez. 2007.

Companhia de Jesus. Ratio studiorum. In: Franca, Leonel. O método pedagógico dos jesuitas. Rio de Janeiro: Livraria Agir Editora, 1952. p. 119-230.

Constituições da Companhia de Jesus e normas complementares. São Paulo: Edições Loyola, 1997. 503 p.

Costa, Lúcio. A arquitetura dos jesuítas no Brasil. Revista do Serviço do Patrimônio Histórico e Artístico Nacional, Rio de Janeiro, Ministério da Educação e Saúde (MES), n. 5, p. 9-104, 1945.

Cunha, Luiz Antônio. O ensino de ofícios artesanais e manufatureiros no Brasil escravocrata. São Paulo: Editora da UNESP; Brasília: FLACSO, 2005.

D. JoÃo III, rei de Portugal. Carta a D. Duarte da Costa, governador do Brasil (Lisboa, 21 de março de 1554). In: Leite, Serafim (Org.). Cartas dos primeiros jesuitas do Brasil. Coimbra: Tipografia da Atlântida, 1957, v. II. p. 35-37.

D. Sebastião I, rei de Portugal. Padrão de redizima de todos os dízimos e direitos que pertencerem a el-rei em todo o Brasil de que sua alteza faz esmola para sempre pera sustentação do Collegio da Baya (1564). In: Leite, Serafim. História da Companbia de Jesus no Brasil. Lisboa: Livraria Portugália; Rio de Janeiro: Civilização Brasileira, 1938, t. I. p. 538-540.

Ferreira Jr., Amarilio; Bittar, Marisa. Pluralidade linguística, escola de bê-á-bá e teatro jesuítico no Brasil do século XVI. Educação E̋ Sociedade, Campinas, CEDES, v. 25, n. 86, p. 171-195, abr. 2004.

Fonseca, Celso Suckow da. História do ensino industrial no Brasil. Rio de Janeiro: Tipografia da Escola Técnica Nacional, 1961, v. I. 670 p.

FrANCA, Leonel. Introdução. In: Livraria Agir Editora, 1952a. p. 5-118. . O método pedagógico dos jesuítas. Rio de Janeiro: . O método pedagógico dos jesuitas. Rio de Janeiro: Livraria Agir Editora, 1952b. $236 \mathrm{p}$.

Grã, Luís da. Carta de Luís da Grã ao P. Inácio de Loyola, Roma (Baía, 27 de dezembro de 1554). In: Leite, Serafim (Org.). Cartas dos primeiros jesuitas do Brasil (1553-1558). Coimbra: Tipografia da Atlântida, 1957, t. II. p. 128-139.

Gramsci, Antonio. Caderno 12 (1932): apontamentos e notas dispersas para um grupo de ensaios sobre a história dos intelectuais. In: - Cadernos do cárcere: os 
intelectuais. O princípio educativo. Jornalismo. Tradução de Carlos Nelson Coutinho. Rio de Janeiro: Civilização Brasileira, 2000, v. 2. p. 13-64.

Gusmão, Alexandre de. Arte de criar bem os filhos na idade da puerícia. São Paulo: Martins Fontes, 2004. 305 p.

Leite, Serafim. História da Companhia de Jesus no Brasil. Lisboa: Livraria Portugália; Rio de Janeiro: Civilização Brasileira, 1938a, t. I. 610 p.

- História da Companbia de Jesus no Brasil. Lisboa: Livraria Portugália; Rio de Janeiro: Civilização Brasileira, 1938b, t. II. 658 p.

. História da Companbia de Jesus no Brasil. Rio de Janeiro: Instituto Nacional do Livro; Lisboa: Livraria Portugália; 1945, t. V. 635 p.

. História da Companhia de Jesus no Brasil. Rio de Janeiro: Instituto Nacional do Livro, 1949, t. VII. 490 p.

. História da Companbia de Jesus no Brasil. Rio de Janeiro: Instituto Nacional do Livro, 1950, t. X. 316 p.

. Artes e ofícios dos jesuitas no Brasil (1549-1760). Lisboa: Edições Brotéria; Rio de Janeiro: Livros de Portugal, 1953. 324 p.

Loi, Vicenzo. Latim cristão. In: Bernardino, Ângelo Di (Org.). Dicionário patrístico e de antiguidades cristãs. Tradução de Cristina Andrade. Petrópolis: Vozes, 2002.p. 808-811. LukÁcs, Ladislau (Org.). Monumenta paedagogica societatis iesu (1586-1591-1599). Ratio atque Institutio Studiorum Societatis Iesu. Roma: Institutum Historicum Societatis Iesu (Monumenta Historica S.I., 129), v. V, 1986. 470 p.

Madureira, José Manuel. A liberdade dos índios. A Companhia de Jesus sua pedagogia e seus resultados. Rio de Janeiro: Imprensa Nacional, 1927.675 p.

Manacorda, Mario Alighiero. História da educação: da Antiguidade aos nossos dias. Tradução de Gaetano Lo Monaco. São Paulo: Cortez; Autores Associados, 1989. 382 p. Nóbrega, Manuel da. Carta ao P. Diego Laynes, Roma (São Vicente, 12 de junho de 1561).In: Cartas do Brasil e mais escritos. Introdução e Notas Históricas e Críticas de Serafim Leite. Coimbra: Universidade de Coimbra, 1955. p. 381-394.

Carta do P. Manuel da Nóbrega ao P. Simão Rodrigues, Lisboa (Baía, 9 de agosto de 1549). In: Leite, Serafim (Org.). Cartas dos primeiros jesuitas do Brasil (1538-1553). Coimbra: Tipografia da Atlântida, 1956a, t. I. p. 119-132.

. Carta do P. Manuel da Nóbrega ao P. Luís Gonçalves da Câmara, Lisboa (São Vicente, 15 de junho de 1553). In: Leite, Serafim (Org.). Cartas dos primeiros jesuitas do Brasil (1538-1553). Coimbra: Tipografia da Atlântida, 1956b, t. I. p. 489-503.

Carta ao P. Miguel de Torres, Lisboa (Baía, 8 de maio de 1558). In: Leite, Serafim (Org.). Cartas dos primeiros jesuitas do Brasil (1553-1558). Coimbra: Tipografia da Atlântida, 1957, t. II. p. 445-459.

Pires, António. Carta do P. António Pires aos padres e irmãos de Coimbra (Pernambuco, 2 de agosto de 1551). In: Leite, Serafim (Org.). Cartas dos primeiros jesuítas do Brasil (1538-1553). Coimbra: Tipografia da Atlântida, 1956, v. I. p. 250-264. 
Pisano, Stephen. Traduções antigas da Bíblia. In: Lacoste, Jean-Yves (Org.). Dicionário crítico de teologia. Tradução de Paulo Meneses et al. São Paulo: Paulinas; Edições Loyola, 2004. p. 1.752-1.755.

Rugiu, Antonio Santoni. Nostalgia do mestre artesão. Tradução de Maria de Lourdes Menon. Campinas: Autores Associados, 1998.

Vieira, Antonio. Sermão da epifania. In: Sermões. Porto: Lello \& Irmão, Editores, 1945, v. II. p. 5-65.

\section{SOBRE OS AUTORES}

Amarilio Ferreira Jr. é doutor em história social pela Universidade de São Paulo (USP). Professor da Universidade Federal de São Carlos (UFSCar). E-mail:ferreira@ufscar.br

Marisa Bittar é doutora em história social pela Universidade de São Paulo (USP). Professora titular da Universidade Federal de São Carlos (UFSCar). E-mail:bittar@ufscar.br 


\section{AMARILIO FERREIRA JR. E MARISA BITTAR}

\section{Artes liberais e ofícios mecânicos nos colégios jesuíticos do Brasil colonial}

Com base em fontes documentais, examinamos neste artigo a prática pedagógica da Companhia de Jesus no Brasil colonial buscando elementos que configuram a relação entre o ensino de humanidades, principal função dos colégios jesuíticos, e a instrução de ofícios manuais. Os resultados obtidos na pesquisa permitem afirmar que houve imbricação entre artes liberais e artes mecânicas, sendo estas complementares em relação àquelas. Tal fato se explica porque os colégios, no contexto da escravidão, necessitaram construir oficinas anexas nas quais eram produzidas as manufaturas necessárias ao seu próprio consumo. Nessas oficinas, os padres instruíam alunos por meio do método semelhante ao das corporações de ofício medievais. Com base nos dados encontrados, é possível afirmar também que a prática pedagógica da Companhia de Jesus no Brasil colonial extrapolou as determinações do Ratio studiorum e das Constituições..., documentos que preceituavam a educação jesuítica em todo o mundo.

mecânicas.

Palavras-chave: educação e trabalho; colégios jesuíticos; artes liberais; artes 


\section{Liberal arts and mechanical crafts in jesuit schools in colonial Brazil}

Using documentary sources, in this article, we examine the pedagogical practices of the Society of Jesus in colonial Brazil, seeking elements that shaped the relation between the teaching of humanities, the primary function of Jesuit schools, and instruction in manual crafts. The results of the research reveal that there was an imbrication between liberal arts and instruction in mechanical crafts, the latter being complementary to the former. This explains why, in the context of slavery, schools needed to build attached workshops, in which manufactured products necessary for their own consumption were produced. In the workshops, the priests instructed students using a method similar to that of the medieval craft guilds. Based on the data obtained, it is also possible to affirm that the pedagogical practices of the Society ofJesus in colonial Brazil went beyond the stipulations of the Ratio studiorum and the Constitutions, documents which defined the precepts of Jesuit education worldwide.

Keywords: Education and work; Jesuit schools; liberal arts; mechanical crafts.

\section{Artes liberales y oficios mecánicos en los colegios jesuitas del Brasil colonial}

Sobre la base de fuentes documentales, en este artículo se reflexiona sobre la práctica pedagógica de la Compañia de Jesús en el Brasil colonial buscando elementos que dan forma a la relación entre la enseñanza de las humanidades, principal función de los colegios jesuitas, y la instrucción en oficios manuales. Los resultados obtenidos en la investigación permiten afirmar que hubo una imbricación entre las artes liberales y artes mecánicas, siendo estas ultimas complementarias a las primeras. Este hecho explica porquélos colegios en el contexto de la esclavitud necesitaban construir talleres auxiliares en los que se producian las manufacturas necesarias para su propio consumo. En esos talleres, los sacerdotes instruyeron a los estudiantes por medio de un método similar al de los gremios medievales de oficios. Sobre la base de los datos encontrados, se puede decir también que la práctica pedagógica de la Compañia de Jesús en el Brasil colonial fue más allá de lo establecido en el Ratio studiorum y en las Constituciones, documentos de preceptos de la educación de la Compañía en todo el mundo.

Palabras clave: educación y trabajo; colegios jesuitas; humanidades; artes mecánicas. 